Zeszyty Naukowe Szkoły Głównej Gospodarstwa Wiejskiego w Warszawie

Problemy Rolnictwa Światowego tom 19 (XXXIV), zeszyt 1, 2019: 110-119

DOI: $10.22630 /$ PRS.2019.19.1.10

Agnieszka Strzelecka ${ }^{1}$, Agnieszka Kurdyś-Kujawska², Danuta Zawadzka ${ }^{3}$

Politechnika Koszalińska

\title{
Kapitał obcy a potencjał wytwórczy i wyniki produkcyjno- ekonomiczne towarowych gospodarstw rolnych
}

\section{Debt Versus Production Potential as Well as Production and Economic Results of Commodity Farms}

\begin{abstract}
Synopsis. Celem badania jest odpowiedź na pytanie: czy wykorzystanie kapitału obcego przez towarowe gospodarstwa rolne przyczynia się do zwiększenia potencjału wytwórczego oraz poprawy warunków produkcyjno-ekonomicznych? Badania przeprowadzono w oparciu o dane zebrane w ramach Polskiego FADN dla 2015 roku. Próba badawcza liczyła 12021 towarowych gospodarstw rolnych, w tym blisko połowa (48,61\%), obok kapitału własnego korzystała także z zewnętrznych źródeł finansowania działalności rolniczej. Ze względu na silną asymetrię, do opisu cech charakteryzujących badane podmioty wykorzystano miary pozycyjne. Do oceny istotności różnic rozkładów zastosowano test sumy rang $U$ Manna-Whitney'a. Uzyskane wyniki badań wskazują na występowanie istotnych różnic $\mathrm{w}$ potencjale produkcyjnym oraz efektywności produkcyjnej i ekonomicznej podmiotów finansujących działalność rolniczą kapitałem obcym i gospodarstw, które korzystają wyłącznie z kapitału własnego. Podmioty, które wykorzystują do finansowania działalności rolniczej, obok kapitału własnego, także kapitał obcy, charakteryzują się wyższym potencjałem wytwórczym oraz uzyskują wyższe wyniki produkcyjno-ekonomiczne, niż gospodarstwa korzystające tylko z kapitału własnego.
\end{abstract}

Slowa kluczowe: kapitał obcy, potencjał produkcyjny, wyniki produkcyjno-ekonomiczne, towarowe gospodarstwo rolne, test $U$ Manna-Whitney'a

\begin{abstract}
The aim of the research is to find an answer to the question: Does the use of debt by commodity farms contribute to the increase of production potential and improvement of production and economic conditions? The research was based on data collected as part of the Polish FADN for 2015. The research sample consisted of 12021 commodity farms, of which almost half (48.61\%), apart from equity also used external sources of financing agricultural activity. To describe the features characterizing the studied entities, positional measures were used due to strong asymmetry. The U Mann-Whitney rank sum test was used to assess the significance of differences in distributions. The obtained research results indicate the existence of significant differences in production potential as well as production and economic efficiency of commodity farms financing agricultural activity with debt and farms that use only own capital. Entities that use debt to finance agricultural activities, apart from equity, are characterized by a higher production potential and obtain higher production and economic results than farms using only equity.
\end{abstract}

Key words: debt, production potential, production and economic results, commodity farm, U MannWhitney rank sum test

JEL Classification: Q11, Q14

${ }^{1}$ dr, Katedra Finansów, Wydział Nauk Ekonomicznych, Politechnika Koszalińska, ul. Kwiatkowskiego 6e, 75-343 Koszalin, agnieszka.strzelecka@tu.koszalin.pl; https://orcid.org/0000-0003-4803-0092

${ }^{2}$ dr, e-mail: agnieszka.kurdys-kujawska@tu.koszalin.pl; https://orcid.org/0000-0002-6024-2947

${ }^{3}$ dr hab., prof. PK, e-mail: danuta.zawadzka@tu.koszalin.pl; https://orcid.org/0000-0001-9353-5941 


\section{Wprowadzenie}

Gospodarstwa rolne mają wiele możliwości finansowania produkcji. Podstawowy katalog źródeł kapitału dzieli je na własne i obce. Pierwsze z wymienionych stanowia dominującą formę finansowania w rolnictwie (Felczak, 2015, s. 83-91). Jednostki z sektora rolnego cechuje wysoki poziom samofinansowania, co wynika z ograniczeń w dostępie do kapitału obcego, będących skutkiem między innymi niskiej akumulacji kapitału własnego (stanowiącego potencjalne zabezpieczenie dla kredytodawcy (Felczak, Domańska, 2014, s. 6)), wysokiego ryzyka operacyjnego w rolnictwie (Zawadzka, 2013, s. 619-630), wysokiej asymetrii informacji (Posey, Reichert , 2011, s. 45-59; Ma, Tian, 2006, s. 114; Zawadzka, 2012, s. 331-339; Kata, 2008, s. 127) oraz awersji rolników do zadłużania się (por. MądraSawicka, 2017, s. 121-134; Mądra-Sawicka, 2015, s. 87-98; Gałecka-Pyra, 2016, s. 89-94; Kata, 2010, s. 146; Zawadzka, Strzelecka, 2014, s. 365-376). Wykorzystanie kapitału obcego, obok niekorzystnego wzrostu ryzyka finansowego, może wiązać się z szeregiem korzyści mających wymiar finansowy (Grzelak, 2005, s. 116-123; Wasilewski, Mądra, 2008, s. 87-99), wynikających głównie z efektu dźwigni finansowej, efektu skali oraz zwiększenia aktywności inwestycyjnej gospodarstw rolnych (por. Zawadzka, SzafraniecSiluta, Ardan, 2016, s. 335-351; Szafraniec-Siluta, Zawadzka, 2017, s. 282-288). Struktura kapitału wpływa na wyniki produkcyjno-ekonomiczne podmiotów z sektora rolnego. Właściwe wykorzystanie zewnętrznych źródeł finansowania działalności rolniczej może przyczynić się do wzrostu potencjału wytwórczego, wydajności pracy i osiaganych dochodów oraz może przyczynić się do poprawy pozycji konkurencyjnej gospodarstwa na rynku (por. Wasilewski, Mądra, 2008, s. 87-99; Stefko, 2008, s. 135-143).

Podstawowym celem badań jest odpowiedź na pytanie: czy wykorzystanie kapitału obcego przez towarowe gospodarstwa rolne przyczynia się do zwiększenia potencjału wytwórczego oraz poprawy warunków produkcyjno-ekonomicznych? Sformułowano następujące hipotezy badawcze: (1) Potencjat wytwórczy oraz wyniki produkcyjnoekonomiczne gospodarstw rolnych sq zróżnicowane ze względu na wykorzystane źródta finansowania działalności. (2) Gospodarstwa, które wykorzystuja do finansowania działalności rolniczej, obok kapitału własnego, także kapitat obcy, charakteryzuja sie wyższym potencjałem wytwórczym oraz uzyskuja wyższe wyniki produkcyjno-ekonomiczne, niż podmioty korzystajace tylko z kapitału własnego.

\section{Materiał i metody badawcze}

W badaniu wykorzystano dane dotyczące $12021^{4}$ towarowych indywidualnych gospodarstw rolnych w Polsce, które w 2015 roku prowadziły rachunkowość rolną na potrzeby systemu zbierania danych rachunkowych z gospodarstw rolnych (Polski FADN). Spośród podmiotów uwzględnionych w analizie, blisko połowa $(48,61 \%)$, obok kapitału własnego korzystała także z zewnętrznych źródeł finansowania działalności rolniczej.

\footnotetext{
${ }^{4} \mathrm{Na}$ potrzeby prowadzonych badań, z populacji towarowych indywidualnych gospodarstw rolnych, które w 2015 roku uczestniczyły w systemie Polskiego FADN (12 105 gospodarstw) wyeliminowano te jednostki, w których nie użytkowano gruntów rolnych (powierzchnia $U R=0$ ha) lub ich powierzchnia była mniejsza niż 1 ha UR. Należą one do grupy podmiotów, które znacząco odbiegają (pod względem wyników produkcyjno-ekonomicznych) od jednostek przeciętnych (por. Wrzaszcz, Prandecki, 2015, s. 17).
} 


\section{A. Strzelecka, A. Kurdyś-Kujawska, D. Zawadzka}

Przeciętne zadłużenie wśród gospodarstw korzystających $\mathrm{z}$ zewnętrznych źródeł finansowania wyniosło 232,03 tys. zł, przy czym połowa zbiorowości charakteryzowała się poziomem zadłużenia niższym niż 98,5 tys. Zobowiązania gospodarstw rolnych (korzystających z kapitału obcego) stanowiły przeciętnie 7,3\% w strukturze źródeł finansowania działalności. Wyniki te potwierdzają tezę o wysokim stopniu samofinansowania podmiotów z sektora rolnego oraz ich niskiej skłonności do zadłużania się. W strukturze obcych źródeł finansowania analizowanej zbiorowości dominowały kredyty długoterminowe, które stanowiły średnio 62,5\% wszystkich zobowiązań (mediana $75 \%$ ). Potwierdza to wyniki badań dotychczas prezentowane w literaturze o dominującym znaczeniu zobowiązań długoterminowych $\mathrm{w}$ strukturze zewnętrznych źródeł finansowania działalności rolniczej (por. m.in.: Mądra, 2010, s. 436-446; Felczak, Domańska, 2014, s. 518; Strzelecka, 2012, s. 234-245).

$\mathrm{Na}$ podstawie przesłanek merytorycznych oraz dostępności danych, do badania przyjęto zmienne, które określają: a) potencjat produkcyjny gospodarstw rolnych - w analizie uwzględniono zasoby ziemi, pracy i kapitału, które stanowią podstawę potencjału wytwórczego gospodarstwa i w dużym stopniu determinują możliwości rozwojowe rolnictwa (por.: Kaczmarek, 2006, s. 27; Poczta, Średzińska, 2007, s. 435) oraz b) wyniki produkcyjno-ekonomiczne $i$ finansowe gospodarstw rolnych. Zbiór zmiennych diagnostycznych uwzględnionych $\mathrm{w}$ analizie oraz ich charakterystykę przedstawiono $\mathrm{w}$ tabeli 1.

Do weryfikacji przyjętych w pracy hipotez badawczych zastosowano nieparametryczny test U Manna-Whitney'a. Test ten weryfikuje hipotezę o istotnych różnicach między rozkładami cech $\mathrm{w}$ dwóch niezależnych populacjach. Obliczenia wykonano przy zastosowaniu programu Statistica 13.

Tabela 1. Charakterystyka zmiennych diagnostycznych uwzględnionych w badaniu

Table 1. Characteristics of diagnostic variables used in the study

\begin{tabular}{l|l}
\hline \multicolumn{1}{c}{ Zmienna } & \multicolumn{1}{c}{ Charakterystyka } \\
\hline \multicolumn{3}{c}{ Potencjal produkcyjny towarowych gospodarstw rolnych } \\
\hline \multicolumn{1}{c}{ Ziemia } \\
\hline $\begin{array}{l}\text { Użytki rolne [ha] } \\
\text { użytki rolne [\%] }\end{array}$ & $\begin{array}{l}\text { Zmienna określająca całkowity obszar ziemi użytkowanej rolniczo. (SE025)* } \\
\text { ogółem, dotyczy dzierżawy na okres co najmniej 1 roku. (SE030/SE025) }\end{array}$ \\
\hline Grunty orne [\%] & Zmienna określająca udział gruntów ornych w powierzchni UR ogółem. (GO_IL/SE025) \\
\hline \multicolumn{1}{c}{ Praca } \\
\hline $\begin{array}{l}\text { Nakłady pracy } \\
\text { ogółem [AWU] }\end{array}$ & $\begin{array}{l}\text { Zmienna określająca całkowity nakład pracy ludzkiej (własnej i najemnej) w ramach } \\
\text { działalności operacyjnej gospodarstwa rolnego. AWU (Annual Work Unit) - jednostka } \\
\text { przeliczeniowa pracy, ekwiwalent 2120 godzin pracy na rok [Floriańczyk, Osuch, } \\
\text { Płonka, 2016, s. 4, 7]. (SE010) }\end{array}$ \\
\hline $\begin{array}{l}\text { Nakłady pracy } \\
\text { własnej [FWU] }\end{array}$ & $\begin{array}{l}\text { Zmienna określająca nakłady pracy własnej (osób nieopłaconych, głównie członków } \\
\text { rodziny) w ramach działalności operacyjnej gospodarstwa rolnego. Nakład ten wyrażony } \\
\text { jest w jednostkach przeliczeniowych pracy (osobach pełnozatrudnionych rodziny). FWU } \\
\text { (Family Work Unit) - jednostka przeliczeniowa pracy członków rodziny, ekwiwalent } \\
\text { 2120 godzin pracy na rok [Floriańczyk, Osuch, Płonka, 2016, s. 4, 7]. (SE015) }\end{array}$ \\
\hline
\end{tabular}


Kapitał obcy a potencjat wytwórczy $i$ wyniki produkcyjno-ekonomiczne...

\begin{tabular}{|c|c|}
\hline Zmienna & Charakterystyka \\
\hline \multicolumn{2}{|r|}{ Relacje między czynnikami produkcji } \\
\hline $\begin{array}{l}\text { Wyposażenie } \\
\text { pracy w ziemię } \\
{[\text { ha/AWU] }}\end{array}$ & $\begin{array}{l}\text { Zmienna określająca wyposażenie pracy w ziemię. Poziom wskaźnika ustalono jako } \\
\text { relację powierzchni użytków rolnych do nakładów pracy ogółem. (SE025/SE010) }\end{array}$ \\
\hline $\begin{array}{l}\text { Techniczne } \\
\text { uzbrojenie ziemi } \\
\text { [tys. zł/ha] }\end{array}$ & $\begin{array}{l}\text { Zmienna określająca techniczne uzbrojenie ziemi. Poziom wskaźnika ustalono jako } \\
\text { relację aktywów trwałych do powierzchni użytków rolnych. (SE441/SE025) }\end{array}$ \\
\hline $\begin{array}{l}\text { Techniczne } \\
\text { uzbrojenie pracy } \\
\text { [tys. zł/AWU] }\end{array}$ & $\begin{array}{l}\text { Zmienna określająca techniczne uzbrojenie pracy. Poziom wskaźnika ustalono jako } \\
\text { relację aktywów trwałych do liczby osób pełnozatrudnionych. (SE441/SE010) }\end{array}$ \\
\hline \multicolumn{2}{|r|}{ Wyniki produkcyjno-ekonomiczne towarowych gospodarstw rolnych } \\
\hline \multicolumn{2}{|r|}{ Produktywność i dochodowość ziemi } \\
\hline $\begin{array}{l}\text { Produktywność } \\
\text { ziemi } \\
\text { [tys. zł/ha] }\end{array}$ & $\begin{array}{l}\text { Zmienna określająca produktywność ziemi użytkowanej rolniczo. Poziom wskaźnika } \\
\text { ustalono jako relację całkowitej produkcji wytworzonej przez gospodarstwo rolne do } \\
\text { powierzchni użytków rolnych. (SE131/SE025) }\end{array}$ \\
\hline $\begin{array}{l}\text { Dochodowość } \\
\text { (rentowność) } \\
\text { ziemi [tys. zł/ha] }\end{array}$ & $\begin{array}{l}\text { Zmienna określająca dochodowość ziemi użytkowanej rolniczo. Wskaźnik obliczono } \\
\text { jako relację dochodu z rodzinnego gospodarstwa rolnego do powierzchni UR } \\
\text { gospodarstwa [por. Wasilewski, Mądra, 2008, s. 91]. Jako miarę dochodu netto przyjęto } \\
\text { dochód z rodzinnego gospodarstwa rolnego. Jest to nadwyżka ekonomiczna, która } \\
\text { pozostaje rolnikowi na opłacenie zaangażowanych w działalność operacyjną } \\
\text { gospodarstwa rolnego czynników wytwórczych (ziemi, pracy oraz kapitału) } \\
\text { stanowiących jego własność [Goraj, Olewnik, 2011, s. 64]. Dochód netto stanowi zatem } \\
\text { syntetyczną miarę poziomu wynagrodzenia nieodpłatnych zasobów pracy, } \\
\text { wynagrodzenia zaangażowanego kapitału, a także renty z tytułu własności ziemi [Gołaś, } \\
\text { 2015, s. 20]. (SE420/SE025). }\end{array}$ \\
\hline \multicolumn{2}{|r|}{ Wydajność i dochodowość pracy } \\
\hline $\begin{array}{l}\text { Wydajność } \\
\text { nakładów pracy } \\
\text { [tys. zł/AWU] }\end{array}$ & $\begin{array}{l}\text { Zmienna określająca wydajność całkowitego nakładu pracy ludzkiej (własnej i } \\
\text { najemnej). Poziom wskaźnika ustalono jako relacje całkowitej produkcji wytworzonej } \\
\text { przez gospodarstwo rolne do liczby osób pełnozatrudnionych. (SE131/SE010) }\end{array}$ \\
\hline $\begin{array}{l}\text { Dochodowość } \\
\text { pracy ogółem } \\
\text { [tys. zł/AWU] }\end{array}$ & $\begin{array}{l}\text { Zmienna określająca dochodowość pracy ogółem. Poziom wskaźnika ustalono jako } \\
\text { relację wartości dodanej netto do liczby osób pełnozatrudnionych. Wartość dodana netto } \\
\text { jest nadwyżką ekonomiczna, która odzwierciedla zrealizowaną opłatę dla wszystkich } \\
\text { czynników produkcji zaangażowanych w działalność operacyjną gospodarstwa rolnego } \\
\text { (ziemi, kapitału oraz całkowitych nakładów pracy), bez względu na to, kto jest } \\
\text { właścicielem tych czynników. [Szerzej: Goraj, 2008, s. 19]. (SE425) }\end{array}$ \\
\hline $\begin{array}{l}\text { Dochodowość } \\
\text { pracy własnej } \\
\text { [tys. zł/FWU] }\end{array}$ & $\begin{array}{l}\text { Zmienna określająca dochodowość pracy własnej. Poziom wskaźnika ustalono jako } \\
\text { relację dochodu z rodzinnego gospodarstwa rolnego do liczby osób pełnozatrudnionych } \\
\text { rodziny [por. Gołaś, 2015, s. 21; Wasilewski, Mądra 2008, s. 92-93]. (SE430) }\end{array}$ \\
\hline \multicolumn{2}{|r|}{ Produktywność i rentowność kapitalu } \\
\hline $\begin{array}{l}\text { Produktywność } \\
\text { aktywów ogółem } \\
{[\%]}\end{array}$ & $\begin{array}{l}\text { Zmienna określająca produktywność majątku (trwałego i obrotowego) zaangażowanego } \\
\text { w działalność gospodarstwa rolnego. Poziom wskaźnika ustalono, jako relację produkcji } \\
\text { ogółem do średniego stanu aktywów ogółem. (SE131/SE436) }\end{array}$ \\
\hline $\begin{array}{l}\text { Rentowność } \\
\text { aktywów ogółem } \\
{[\%]}\end{array}$ & $\begin{array}{l}\text { Zmienna określająca rentowność aktywów ogółem. Poziom wskaźnika ustalono jako } \\
\text { relację dochodu z rodzinnego gospodarstwa rolnego (pomniejszonego o koszty pracy } \\
\text { własnej) do średniego stanu aktywów ogółem. (RAKTOG) }\end{array}$ \\
\hline $\begin{array}{l}\text { Rentowność } \\
\text { kapitału własnego } \\
{[\%]}\end{array}$ & $\begin{array}{l}\text { Zmienna określająca rentowność kapitału własnego. Poziom wskaźnika ustalono jako } \\
\text { relacje dochodu z rodzinnego gospodarstwa rolnego (pomniejszonego o koszty pracy } \\
\text { własnej) do średniego stanu kapitału własnego. (RKAPWL) }\end{array}$ \\
\hline \multicolumn{2}{|c|}{$\begin{array}{l}\text { * W nawiasach podano odniesienia do symboli poszczególnych zmiennych według FADN. Podstawo } \\
\text { charakterystyki zmiennych na podstawie: (Floriańczyk, Osuch, Płonka, 2016, s. 17-32). }\end{array}$} \\
\hline \multicolumn{2}{|c|}{$\begin{array}{l}\text { Źródło: opracowanie własne na podstawie: (Poczta, Średzińska, 2007, s. 433-443; Poczta, Średzińska, Standar, } \\
\text { 2008, s. 83-94; Średzińska, 2017, s. 305-314; Floriańczyk, Osuch, Płonka, 2016, s. 17-32; Poczta, Średzińska, } \\
\text { Pawlak, 2008, 379-387; Wrzaszcz, Prandecki, 2015, s. 16-39; Wrzaszcz, 2017, s. 3-169; Wasilewski, Mądra, } \\
\text { 2008, s. 87-99; Goraj, 2008, s. 19; Siemiński, 2015, s. 246-252; Gołaś, 2015, s. 21). }\end{array}$} \\
\hline
\end{tabular}




\section{Wyniki badań}

Pierwszy etap badań obejmował ustalenie różnic $\mathrm{w}$ potencjale produkcyjnym gospodarstw rolnych. Uzyskane w tym zakresie wyniki przedstawiono w tabeli 2.

Wyższym potencjałem produkcyjnym, zarówno w zakresie czynnika ziemi, pracy, jak i kapitału, charakteryzowały się gospodarstwa, które angażowały obce źródła do finansowania prowadzonej działalności. Wskazują na to wartości przeciętne (mediana) poszczególnych wskaźników uwzględnionych w badaniu, jak też ich maksymalne wartości. W zakresie podstawowego czynnika produkcji w rolnictwie, jakim jest ziemia, ustalono, że w 2015 roku przeciętna powierzchnia użytków rolnych (UR) gospodarstw, które posiadały zobowiązania wyniosła 35,60 ha, i była wyższa od przeciętnej wartości charakteryzującej podmioty wykorzystujące wyłącznie kapitał własny w finansowaniu działalności rolniczej (17,81 ha). Należy w tym miejscu podkreślić, że obie wyodrębnione grupy podmiotów charakteryzowały się wyższym przeciętnym obszarem ziemi użytkowanej rolniczo, od średniej powierzchni gospodarstwa rolnego w Polsce, która w 2015 roku wyniosła 10,49 ha (Ogłoszenie Prezesa..., 2015). Istotne różnice zaobserwowano dla maksymalnej powierzchni ziemi użytkowanej rolniczo, która w przypadku jednostek wykorzystujących obce źródła finansowania wyniosła 703,43 ha, natomiast w drugiej grupie uwzględnionej w badaniu była niższa i wyniosła 586,17 ha. Ponadto gospodarstwa posiadające zobowiązania charakteryzowały się wyższym przeciętnym udziałem ziemi dodzierżawionej $(22,35 \%)$ oraz wyższym przeciętnym udziałem gruntów ornych $(92,08 \%)$, niż podmioty finansujące się wyłącznie kapitałem własnym, dla których wartości te wyniosły odpowiednio: $6,85 \%$ ha oraz $86,62 \%$. Analizując czynnik pracy ustalono, że gospodarstwa rolne posiadające zobowiązania angażowały w procesie produkcji od 0,21 do 29,65 AWU. Dla jednostek finansujących się wyłącznie kapitałem własnym nakłady te były nieco niższe i wyniosły od 0,11 do 24,45 AWU. Przy czym w obu analizowanych grupach przeciętny nakład omawianego czynnika produkcji (ustalony na podstawie mediany) nie przekraczał 2 osób pełnozatrudnionych ogółem oraz dwóch osób pełnozatrudnionych rodziny. Gospodarstwa rolne korzystające z kapitału obcego dysponowały majątkiem o wartości od 78,67 tys. zł do 30 229,26 tys. zł, przy czym dla połowy jednostek z tej grupy wartość aktywów ogółem nie przekraczała 1415,85 tys. zł. Znacznie niższe wartości analizowanego czynnika produkcji odnotowano dla podmiotów, które nie posiadały zobowiązań (od 19,01 tys. zł do 18 436,32 tys. zł). Dla połowy gospodarstw z tej grupy wartość aktywów ogółem była niższa od 673,08 tys. zł. Zaobserwowano także, że wskaźniki dotyczące zarówno wyposażenia pracy $\mathrm{w}$ ziemię, technicznego uzbrojenia ziemi, jak też technicznego uzbrojenia pracy, przyjmowały wyższe wartości przeciętne (mierzone medianą) w przypadku gospodarstw posiadających zobowiązania.

Na podstawie wyników nieparametrycznego testu $U$ Manna-Whitney'a odrzucono (na poziomie istotności $\mathrm{p}<0,1$ dla każdej zmiennej uwzględnionej w badaniu) hipotezę zerowa o nieistotności różnic między potencjałem produkcyjnym obu grup gospodarstw, które poddano badaniu. Zatem istnieje statystycznie istotna różnica między potencjałem produkcyjnym gospodarstw rolnych, które wykorzystują obce źródła finansowania w ramach prowadzonej działalności i podmiotów, które do tego celu angażują wyłącznie kapitał własny.

W dalszej kolejności zbadano różnice w zakresie wyników produkcyjnoekonomicznych uzyskiwanych przez gospodarstwa rolne $\mathrm{z}$ wyodrębnionych grup. Otrzymane wyniki przedstawiono w tabeli 3. 
Tabela 2. Potencjał produkcyjny towarowych gospodarstw rolnych ze względu na źródła finansowania działalności rolniczej

Table 2. Production potential of commodity farms according to sources of financing agricultural activity

\begin{tabular}{|c|c|c|c|c|c|c|c|}
\hline Wyszczególnienie & Mediana & Min. & Max. & Kwartyl dolny & Kwartyl górny & Rozstęp & Skośność \\
\hline & \multicolumn{7}{|c|}{ Ziemia } \\
\hline & \multicolumn{7}{|c|}{ Użytki rolne [ha] } \\
\hline GR_ZO & 35,60 & 1,00 & 703,43 & 21,64 & 57,70 & 702,43 & 4,32 \\
\hline \multirow[t]{2}{*}{ N_GR_ZO } & 17,81 & 1,02 & 586,17 & 11,17 & 28,23 & 585,15 & 7,97 \\
\hline & \multicolumn{7}{|c|}{ Dodzierżawione użytki rolne[\%] } \\
\hline GR_ZO & 22,35 & 0,00 & 100,00 & 0,00 & 43,51 & 100,00 & 0,65 \\
\hline \multirow[t]{2}{*}{ N_GR_ZO } & 6,85 & 0,00 & 100,00 & 0,00 & 34,95 & 100,00 & 1,13 \\
\hline & \multicolumn{7}{|c|}{ Grunty orne $[\%]$} \\
\hline GR_ZO & 92,08 & 0,00 & 100,00 & 72,14 & 100,00 & 111,89 & $-1,59$ \\
\hline \multirow[t]{3}{*}{ N_GR_ZO } & 86,62 & 0,00 & 100,00 & 65,37 & 99,03 & 155,61 & $-1,31$ \\
\hline & \multicolumn{7}{|c|}{ Praca } \\
\hline & \multicolumn{7}{|c|}{ Nakłady pracy ogółem [AWU] } \\
\hline GR_ZO & 1,92 & 0,21 & 29,65 & 1,50 & 2,31 & 29,44 & 7,36 \\
\hline \multirow[t]{2}{*}{ N_GR_ZO } & 1,68 & 0,11 & 24,45 & 1,25 & 2,02 & 24,34 & 6,69 \\
\hline & \multicolumn{7}{|c|}{ Nakłady pracy własnej [FWU] } \\
\hline GR_ZO & 1,80 & 0,12 & 4,94 & 1,36 & 2,03 & 4,82 & 0,48 \\
\hline \multirow[t]{3}{*}{ N_GR_ZO } & 1,59 & 0,09 & 4,91 & 1,19 & 2,00 & 4,82 & 0,34 \\
\hline & \multicolumn{7}{|c|}{ Kapitat } \\
\hline & \multicolumn{7}{|c|}{ Aktywa ogółem [ tys. zł] } \\
\hline GR_ZO & 1415,85 & 78,67 & 30229,26 & 886,43 & 2260,71 & 30150,60 & 4,07 \\
\hline \multirow[t]{3}{*}{ N_GR_ZO } & 673,08 & 19,01 & 18436,32 & 420,92 & 1113,67 & 18417,30 & 6,89 \\
\hline & \multicolumn{7}{|c|}{ Relacje między czynnikami produkcji } \\
\hline & \multicolumn{7}{|c|}{ Wyposażenie pracy w ziemię [ha/AWU] } \\
\hline GR_ZO & 19,19 & 0,10 & 230,01 & 11,98 & 31,56 & 229,91 & 2,68 \\
\hline \multirow[t]{2}{*}{ N_GR_ZO } & 11,13 & 0,04 & 283,00 & 6,98 & 17,84 & 282,96 & 4,54 \\
\hline & \multicolumn{7}{|c|}{ Techniczne uzbrojenie ziemi [tys. zł/ha] } \\
\hline GR_ZO & 35,90 & 0,01 & 5172,34 & 25,68 & 48,54 & 5172,33 & 26,99 \\
\hline \multirow[t]{2}{*}{ N_GR_ZO } & 34,51 & 0,00 & 1871,70 & 24,24 & 48,83 & 1871,70 & 21,32 \\
\hline & \multicolumn{7}{|c|}{ Techniczne uzbrojenie pracy [tys. zł/AWU] } \\
\hline GR_ZO & 679,45 & 0,76 & 6860,89 & 417,94 & 1095,67 & 6860,13 & 2,42 \\
\hline N_GR_ZO & 374,45 & 0,00 & 7573,39 & 228,83 & 617,78 & 7573,39 & 3,96 \\
\hline
\end{tabular}


Tabela 3. Wyniki produkcyjno-ekonomiczne towarowych gospodarstw rolnych ze względu na źródła finansowania działalności rolniczej

Table 3. Production and economic results of commodity farms according to sources of financing agricultural activity

\begin{tabular}{|c|c|c|c|c|c|c|c|}
\hline Wyszczególnienie & Mediana & Min. & Max. & $\begin{array}{c}\text { Kwartyl } \\
\text { dolny }\end{array}$ & $\begin{array}{l}\text { Kwartyl } \\
\text { górny }\end{array}$ & Rozstęp & Skośność \\
\hline & \multicolumn{7}{|c|}{ Produktywność i dochodowość ziemi } \\
\hline & \multicolumn{7}{|c|}{ Produktywność ziemi [tys. zł/ha] } \\
\hline GR_ZO & 5,46 & $-1,19$ & 4304,27 & 3,89 & 8,41 & 4305,47 & 42,24 \\
\hline \multirow[t]{2}{*}{ N_GR_ZO } & 4,80 & $-1,45$ & 1982,27 & 3,19 & 7,44 & 1983,72 & 29,99 \\
\hline & \multicolumn{7}{|c|}{ Dochodowość (rentowność) ziemi [tys. zł/ha] } \\
\hline GR_ZO & 1,88 & $-223,10$ & 2116,95 & 1,00 & 3,05 & 2340,05 & 61,23 \\
\hline \multirow[t]{3}{*}{ N_GR_ZO } & 1,65 & $-79,73$ & 268,08 & 0,75 & 2,93 & 347,80 & 16,81 \\
\hline & \multicolumn{7}{|c|}{ Wydajność i dochodowość pracy } \\
\hline & \multicolumn{7}{|c|}{ Wydajność nakładów pracy [tys. zł/AWU] } \\
\hline GR_ZO & 112,97 & $-19,24$ & 1851,17 & 65,31 & 189,74 & 1870,40 & 3,14 \\
\hline \multirow[t]{2}{*}{ N_GR_ZO } & 54,23 & $-49,74$ & 1655,58 & 31,79 & 92,95 & 1705,32 & 4,78 \\
\hline & \multicolumn{7}{|c|}{ Dochodowość pracy ogółem [tys. zł/AWU] } \\
\hline GR_ZO & 42,92 & $-123,76$ & 780,89 & 21,05 & 76,54 & 904,65 & 2,86 \\
\hline \multirow[t]{2}{*}{ N_GR_ZO } & 20,97 & $-112,45$ & 586,53 & 8,63 & 40,01 & 698,98 & 3,50 \\
\hline & \multicolumn{7}{|c|}{ Dochodowość pracy własnej [tys. zł/FWU] } \\
\hline GR_ZO & 40,21 & $-335,62$ & 12457,89 & 18,15 & 77,08 & 12793,52 & 49,32 \\
\hline \multirow[t]{3}{*}{ N_GR_ZO } & 20,18 & $-185,84$ & 2397,28 & 7,66 & 40,68 & 2583,12 & 15,88 \\
\hline & \multicolumn{7}{|c|}{ Produktywność i rentowność kapitału } \\
\hline & \multicolumn{7}{|c|}{ Produktywność aktywów ogółem [\%] } \\
\hline GR_ZO & 14,83 & $-2,29$ & 344,45 & 10,61 & 20,41 & 346,74 & 6,63 \\
\hline \multirow[t]{2}{*}{ N_GR_ZO } & 13,20 & $-3,41$ & 361,97 & 8,77 & 19,11 & 365,38 & 7,49 \\
\hline & \multicolumn{7}{|c|}{ Rentowność aktywów ogółem [\%] } \\
\hline GR_ZO & 0,60 & $-35,49$ & 328,34 & $-2,70$ & 3,83 & 363,83 & 14,37 \\
\hline \multirow[t]{2}{*}{ N_GR_ZO } & $-2,93$ & $-114,21$ & 117,11 & $-7,32$ & 0,93 & 231,32 & 0,63 \\
\hline & \multicolumn{7}{|c|}{ Rentowność kapitału własnego ${ }^{5}[\%]$} \\
\hline GR_ZO & 0,65 & $-52,15$ & 125,37 & $-2,94$ & 4,31 & 177,52 & 3,09 \\
\hline N_GR_ZO & $-2,93$ & $-114,21$ & 117,11 & $-7,32$ & 0,93 & 231,32 & 0,63 \\
\hline
\end{tabular}

GR_Z - gospodarstwa rolne posiadające zobowiązania; N_GR_ZO - gospodarstwa rolne bez zobowiązań

Źródło: opracowanie własne na podstawie danych FADN.

Przeprowadzone badanie wykazało, że wyższe wyniki produkcyjno-ekonomiczne osiągają gospodarstwa rolne, które obok kapitału własnego, angażują także kapitał obcy do finansowania działalności. Przeciętna produktywność ziemi (mierzona mediana) dla tej grupy podmiotów wyniosła 5,46 tys. zł/ha, a przeciętna dochodowość tego czynnika produkcji wyniosła 1,88 tys. zł/ha. Wartości analizowanych wskaźników, odnoszących się do czynnika ziemi, ustalone dla drugiej grupy gospodarstw były niższe i wyniosły odpowiednio: 4,8 tys. zł/ ha oraz 1,65 tys. zł/ha. Ponadto zaobserwowano istotne różnice w zakresie wartości wskaźników dotyczących wydajności i dochodowości pracy wśród wyodrębnionych grup gospodarstw rolnych. Dla połowy podmiotów posiadających zadłużenie przeciętna wartość produkcji wytworzonej przez jednego pracownika była wyższa niż 112,97 tys. zł rocznie, przy czym maksymalna wydajność nakładów pracy w tej

${ }^{5} \mathrm{~W}$ gospodarstwach rolnych, które nie posiadają zadłużenia, rentowność kapitału własnego jest równa rentowności aktywów ogółem. 
grupie wyniosła 1851,17 tys. zł/AWU rocznie. Dla porównania, w przypadku połowy zbiorowości podmiotów finansujących się wyłącznie kapitałem własnym, wydajność ta była niższa niż 54,23 tys. zł/AWU rocznie, a maksymalny poziom analizowanego wskaźnika wyniósł 1655,58 tys. zł/AWU. Przeprowadzane badanie dowodzi także znacznie wyższej dochodowości czynnika pracy wśród gospodarstw rolnych posiadających zobowiązania, niż $\mathrm{w}$ przypadku drugiej $\mathrm{z}$ rozpatrywanych grup (analizując zarówno nakłady pracy ogółem, jak też wyłącznie nakład pracy własnej). Dla połowy zbiorowości korzystającej z kapitału obcego dochód przypadający na jednego zatrudnionego był wyższy niż 42,92 tys. zł, natomiast dla drugiej z rozpatrywanych grup wartość ta była o połowę niższa (20,97 tys. zł/AWU). Analizując wskaźniki dotyczące ostatniego z wyodrębnionych czynników produkcji, mianowicie kapitału, ustalono, że wyższą przeciętną stopą zwrotu z zaangażowanego kapitału własnego oraz wyższą rentownością ekonomiczną cechowały się jednostki, które obok kapitału własnego, angażowały także obce źródła finansowania. Należy także podkreślić, że dla połowy gospodarstw rolnych, które nie posiadały zadłużenia, działalność rolnicza w 2015 roku była nierentowna.

Wyniki nieparametrycznego testu $U$ Manna-Whitney'a umożliwiły odrzucenie (na poziomie istotności $\mathrm{p}<0,1$ dla każdej $\mathrm{z}$ przyjętych zmiennych) hipotezy zerowej o nieistotności różnic między wynikami produkcyjno-ekonomicznymi obu wyodrębnionych grup podmiotów objętych analizą. Zatem istnieje statystycznie istotna różnica między wynikami produkcyjno-ekonomicznymi gospodarstw rolnych posiadających zobowiązania i jednostek, które korzystają wyłącznie z kapitału własnego.

\section{Podsumowanie i wnioski}

Podstawowym celem badań była odpowiedź na pytanie: czy wykorzystanie kapitału obcego przez towarowe gospodarstwa rolne przyczynia się do zwiększenia potencjału wytwórczego oraz poprawy warunków produkcyjno-ekonomicznych? Przeprowadzone badania wykazały występowanie istotnych różnic w potencjale wytwórczym oraz efektywności produkcyjnej i ekonomicznej gospodarstw finansujących działalność rolniczą kapitałem obcym i jednostek, które korzystają wyłącznie z kapitału własnego. Podmioty, które wykorzystują do finansowania działalności rolniczej, obok kapitału własnego, także kapitał obcy, charakteryzują się wyższym potencjałem produkcyjnym, zarówno w zakresie czynnika ziemi, pracy, jak i kapitału oraz uzyskują wyższe wyniki produkcyjnoekonomiczne, niż podmioty samofinansujące się. Gospodarstwa rolne finansujące się kapitałem obcym charakteryzują się znacznie większą powierzchnią użytków rolnych, wyższym udziałem gruntów ornych w powierzchni UR oraz większym udziałem gruntów dzierżawionych. Ponadto podmioty te odznaczają się wyższym poziomem wskaźnika wyposażenia pracy w ziemię, technicznego uzbrojenia ziemi oraz technicznego uzbrojenia pracy. W porównaniu do jednostek samofinansujących się, gospodarstwa rolne korzystające z kapitałów obcych odznaczają się znacznie wyższą produktywnością i dochodowością ziemi, wyższą wydajnością pracy oraz wyższą rentownością aktywów i kapitału. Uzyskane wyniki badań dają podstawę do pozytywnego zweryfikowania postawionych we wstępnie hipotez. 


\section{Bibliografia}

Felczak, T. (2015). Źródła finansowania działalności gospodarstw rolniczych w opinii zarządzających (The sources of financing of agricultural activities according to their managers). ZN US Finanse, Rynki Finansowe, Ubezpieczenia, 74(2), 83-91.

Felczak, T., Domańska T. (2014). Struktura i poziom zadłużenia a efektywność indywidualnych gospodarstw rolniczych w zależności od wielkości ekonomicznej (The structure and level of debt and the efficiency of individual farms, depending on the size of the economic). Zarzadzane Finansami i Rachunkowość, 2(3), 5-18.

Floriańczyk, Z., Osuch, D., Płonka, R. (2016). Wyniki Standardowe 2015 uzyskane przez gospodarstwa rolne uczestniczące w Polskim FADN (Standard results of Polish FADN agricultural holdings). Część I. Wyniki Standardowe, IERiGŻ-PIB, Warszawa.

Gałecka, A., Pyra, M. (2016). Zadłużenie gospodarstw rolniczych w Polsce w latach 2010-2013 (The debt level of agricultural farms in Poland in the years 2010-2013). Roczniki Naukowe Stowarzyszenia Ekonomistów Rolnictwa i Agrobiznesu, 18(2), 89-94.

Gołaś, Z. (2015). Systemy wskaźników dochodowości pracy w rolnictwie - propozycja metodyczna (Systems of work profi tability ratios in agriculture - a methodical proposal). ZN SGGW Ekonomika i Organizacja Gospodarki Żywnościowej, 109, 17-26.

Goraj, L., Olewnik, E. (2011). FADN i Polski FADN (FADN and Polish FADN). IERiGŻ-PIB, Warszawa.

Goraj, L. (2008). Pomiar dochodu z działalności gospodarstwa rolnego. Parametry i definicje (Measurement of income from the activity of the farm. Parameters and definitions). Ubezpieczenia w rolnictwie. Materiały $i$ Studia, nr 33.

Grzelak, A. (2005). Finansowanie zewnętrzne gospodarstw rolnych (Forms of external financing of farms). Wieś $i$ Rolnictwo, 4(129), 116-123.

Kaczmarek, J. (2006). Zróżnicowanie regionalne potencjału produkcyjnego oraz wyników produkcyjnoekonomicznych indywidualnych gospodarstw rolnych w Polsce z uwzględnieniem wybranych typów rolniczych (na podstawie FADN) (Regional diversification of production potential and production and economic results for family farms in Poland with respect to selected types of farming (on the basis of FADN)). ZN SGGW Problemy Rolnictwa Światowego, 15(2006), 26-35.

Kata, R. (2010). Problem wykorzystania kredytu bankowego w finansowaniu rolnictwa w Polsce i innych krajach Unii Europejskiej (Profitability of different weed control methods in potato field). Acta Scientiarum Polonorum Oeconomia, 9(3), 145-156.

Kata, R. (2008). Relacje rolników z instytucjami w aspekcie finansowania gospodarstw ze źródeł zewnętrznych (Farmers' relations with institutions in the aspect of financing farms from external sources). W: D Kopycińska (red.), Konkurencyjność podmiotów rynkowych, Wydawnictwo Uniwersytetu Szczecińskiego, Szczecin.

Ma, J., Tian, G. (2006). Risks, Financing Constraints, and High Savings Ratio in the Rural Economy of China: A Model Incorporating Precautionary Savings and Liquidity Constraints, Frontiers of Economics in China, No. 1(1), January.

Mądra, M. (2010). Czynniki wpływające na zaangażowanie zewnętrznych źródeł finansowania w strukturze kapitału mikroprzedsiębiorstw rolniczych (The fctors which influenced the debt involvement in the agriculture micro enterprices' capital resources). ZN Uniwersytetu Ekonomicznego w Poznaniu 142, 436-446.

Mądra-Sawicka, M. (2017). Finansowanie wewnętrzne małych przedsiębiorstw przetwórstwa spożywczego (Internal financing of small food processing enterprise). ZN US Finanse, Rynki Finansowe, Ubezpieczenia, 4(88), 121-134.

Mądra-Sawicka, M. (2015). Znaczenie wewnętrznych źródeł finansowania w kształtowaniu struktury kapitału przedsiębiorstw rolniczych (The importance of internal sources of financing regard to capital structure decisions in agricultural enterprises). Zarzqdzanie Finansami i Rachunkowość, 3(4), 87-98.

Ogłoszenie Prezesa Agencji Restrukturyzacji i Modernizacji Rolnictwa z dnia 21 września 2015 r., w sprawie w sprawie wielkości średniej powierzchni gruntów rolnych w gospodarstwie rolnym w poszczególnych województwach oraz średniej powierzchni gruntów rolnych w gospodarstwie rolnym w kraju w 2015 roku. ARiMR. Pobrano z: https://www.arimr.gov.pl/pomoc-krajowa/srednia-powierzchnia-gospodarstwa.html.

Poczta, W., Średzińska, J., Pawlak, K. (2008). Sytuacja finansowa gospodarstw rolnych krajów UE sklasyfikowanych według ich wyników produkcyjno-ekonomicznych (Financial situation of the agricultural holdings in the EU countries grouped according to their production and economic results). ZN $S G G W$ Problemy Rolnictwa Światowego, 4, 379-387.

Poczta, W., Średzińska, J., Standar, A. (2008). Sytuacja finansowa gospodarstw rolnych krajów UE według potencjału produkcyjnego (Financial situation in the agricultural holdings of the EU countries according to the potential for production). Journal of Agribusiness and Rural Development, 4(10), 83-94. 
Poczta, W., Średzińska, J. (2007). Wyniki produkcyjno-ekonomiczne i finansowe indywidualnych gospodarstw rolnych według ich wielkości ekonomicznej (na przykładzie regionu FADN Wielkopolska i Śląsk) (Production, economic and financial results in individual agricultural holdings according to their economic size (basing on example of Wielkopolska and Śląsk FADN region)). ZN SGGW Problemy Rolnictwa Światowego, 2, 433-443.

Posey, R., Reichert, A. (2011). A Comparison of Non-price Terms of Lending for Small Business and Farm Loans. The International Journal of Business and Finance Research, 5(2), 45-59

Siemiński, P. (2015). Sytuacja ekonomiczna a kierunki rozwoju małych gospodarstw rolnych (The economic situation and development trends of small farms). Roczniki Naukowe Stowarzyszenia Ekonomistów Rolnictwa i Agrobiznesu, 17(6), 246-252.

Stefko, O. (2008). Aktywność inwestycyjna i umiejętność pozyskania kapitału obcego jako warunki rozwoju i podnoszenia konkurencyjności gospodarstw indywidualnych w Polsce (Investment activity of the agricultural farms and their competence for using borrowed capital as conditions of skills in development and progress of competitiveness of individual farms in Poland). Journal of Agribusiness and Rural Development, 2(8), 135-143.

Strzelecka, A. (2012). Struktura finansowania majątku mikroprzedsiębiorstw rolniczych w Polsce (Assets financing structure of agricultural micro-enterprises in Poland). ZN US Ekonomiczne Problemy Ustug, 80, 234-245.

Szafraniec-Siluta, E., Zawadzka, D. (2017). Struktura nakładów inwestycyjnych na środki trwałe przedsiębiorstw rolniczych w Polsce - ujęcie porównawcze (Structure of investment outlays on fixed assets of agriculure enterprises in Poland - a comparative approach). Roczniki Naukowe Stowarzyszenia Ekonomistów Rolnictwa i Agrobiznesu, 19(3), 282-288.

Średzińska, J. (2017). Czynniki kształtujące dochody gospodarstw rolnych Unii Europejskiej według klas wielkości ekonomicznej (Factors determining income of farms in the European Union according to economic size classes). Prace Naukowe UE we Wrocławiu, 477, 305-314.

Wasilewski, M., Mądra, M. (2008). Efektywność gospodarstw indywidualnych w zależności od zadłużenia i siły ekonomicznej (The efficiency of individual agricultural farms in relation to debt level and european size unit). ZN SGGW Ekonomika i Organizacja Gospodarki Żywnościowej, 64, 87-99.

Wrzaszcz, W., Prandecki, K. (2015). Sprawność ekonomiczna gospodarstw rolnych oddziałujących w różnym zakresie na środowisko przyrodnicze (Economic efficiency of sustainable agriculture). Zagadnienia Ekonomiki Rolnej, 2(343), 16-39.

Wrzaszcz, W. (2017). Wyniki produkcyjno-ekonomiczne gospodarstw rolnych oddziałujących w różnym zakresie na środowisko przyrodnicze (Farms' production and economic results difference in the environmental pressure). Zagadnienia Ekonomiki Rolnej, 2(351), 3-29.

Zawadzka, D. (2013). Kredyt w decyzjach finansowych przedsiębiorstw rolniczych w Polsce (ze szczególnym uwzględnieniem podmiotów $\mathrm{Z}$ regionu Pomorza Środkowego) (Credit in the financial decisions of agricultural companies in Poland (with particular emphasis on the companies in Middle Pomerania)). Zarzqdzanie i Finanse, 2(2), 619-630.

Zawadzka, D. (2012). Ocena wykorzystania kredytu handlowego przez przedsiębiorstwa rolnicze w Polsce (The evaluation of trade credit use by agriculture enterprises in Poland). Studia Ekonomiczne / Uniwersytet Ekonomiczny w Katowicach, 107, 331-339.

Zawadzka, D., Strzelecka, A. (2014). Struktura terminowa zobowiązań przedsiebiorstw rolniczych z tytułu kredytu bankowego - ujęcie porównawcze (Term structure of agricultural companies' bank loan liabilities comparative approach). Prace Naukowe Uniwersytetu Ekonomicznego we Wrocławiu, 326, 365-375.

Zawadzka, D., Szafraniec-Siluta, E., Ardan, R. (2016). Ocena skłonności gospodarstw rolnych Pomorza Środkowego do zadłużania się (Assessment tendency to indebtedness of the Middle Pomerania farms). Studia Prawno-Ekonomiczne, 98, 335-351.

\section{Do cytowania / For citation:}

Strzelecka A., Kurdyś-Kujawska A., Zawadzka D. (2019). Kapitał obcy a potencjał wytwórczy i wyniki produkcyjno-ekonomiczne towarowych gospodarstw rolnych. Problemy Rolnictwa Światowego, 19(1), 110-119; DOI: 10.22630/PRS.2019.19.1.10

Strzelecka A., Kurdyś-Kujawska A., Zawadzka D. (2019). Debt Versus Production Potential as Well as Production and Economic Results of Commodity Farms (in Polish). Problems of World Agriculture, 19(1), 110-119; DOI: 10.22630/PRS.2019.19.1.10 